\title{
Disney Movie Soundtrack: Does It Give Effect to Students' Speaking Skill?
}

\author{
Alda Indah Permana ${ }^{1}$, Fika Megawati ${ }^{2}$ \\ Universitas Muhammadiyah Sidoarjo, Indonesia ${ }^{1,2}$ \\ Email Correspondence: aldaindah100@gmail.com
}

\section{Background:}

Abstract

The implementation of media in the learning process can be a crucial thing to support students' competence. Meanwhile, teacher also has a role to utilize creative media in honing students' English skill especially in speaking. One of the interesting media that can accommodate teaching and learning activities is song. Thus, this study aims at investigating the effect of Disney movie soundtrack to the EFL students' speaking skill.

\section{Methodology:}

This study used quasi-experimental with non-equivalent control group design. The object of this study was two classes which divided as experimental group and control group on the eleventh grade at Islamic boarding school. Furthermore, the data were collected from students' pre-test and post-test scores. The score of test in the experimental group showed the results based on the implementation of treatment using Disney movie soundtrack, while the control group only used conventional learning.

\section{Findings:}

The finding in this study revealed that there is a significant effect toward students' speaking skill after the researcher applied the use of English song especially Disney movie soundtrack as the media during the learning activities. Moreover, it also showed the difference between score of students in experimental group which increased than the results of students' scores in control group. In addition, the learners still have to practice their speaking skill in daily life.

\section{Conclusion:}

In short, the effect of Disney movie soundtrack contributes to support EFL teachers in accommodating speaking class activities to be more interesting and motivating.

Keywords: speaking skill; english song, disney movie.

DOI $\quad$ : http//dx.doi.org/10.24903/sj.v6i2.767

\begin{tabular}{|l|l|l|}
\hline Received & $:$ & August 2021 \\
\hline Accepted & $:$ & September 2021 \\
\hline Published & $:$ & October 2021 \\
\hline
\end{tabular}

Copyright Notice Authors retain copyright and grant the journal right of first publication with the work simultaneously licensed under Creative Commons Attribution 4.0 International License that allows others to share the work with an acknowledgement of the work's authorship and initial publication in this journal. 


\section{INTRODUCTION}

Learning English is considered not easy for students in senior high school especially in enhancing speaking skill. In the process of mastering this skill, most of the learners contemplate that speaking is a difficult skill because they must improve several necessary things such as accuracy, comprehensibility and fluency (Wiraningsih et al., 2016). Meanwhile, speaking known as an important skill which should be mastered because it can make people easy in creating a communication or interaction with others. However, Wahidah (2016) stated that speaking is very crucial for communication and students should realize that this skill always applied in their daily interactions. Regarding with the statement, it means that learners as a foreign language have to be more active in speaking English to support their competence. On the other hand, speaking can be stated as one of productive skills in communication because it can develop students' ideas to be more critical and creative in thinking (Parmawati \& Inayah, 2019).

Furthermore, there are several difficulties which often faced by the learners in improving their speaking skill such as the lack of motivation, students afraid to make a grammar mistake, apprehensive to be criticized, feel less confidence and understanding to speak in English (Tuan \& Mai, 2015). These problems also arise because students lack the enthusiasm for learning and practice this skill. Nevertheless, it is essential for the teacher to know about how to teach the students in improving their speaking skill and the learners must be recognize that this skill has an impact to support students' ability (Al-Sobhi \& Preece, 2018). In line with this statement, it can be concluded that teacher has the main role to make the learners become interested in practice speaking English and they also should be aware to hone their speaking skill well.

According to Al Hosni (2018), there are some students who have less motivation to speak English because they still feel not necessary to apply this skill in their daily interaction. Regarding with the statement, it showed that the lack of students' motivation will impact towards the way they communicate to convey their own identity which connect with people around them. Therefore, teachers are able to utilize the use of song media to develop students' speaking skill effectively. Based on the pre-observation, the English teacher showed that most of students in the Islamic boarding school do not often hone their speaking skills and lack confidence to communicate using English. Therefore, this problem has an impact on students' scores during the exams especially in speaking scores.

Furthermore, song is known as a learning material that has great advantage for the students (Wijaya, 2018). Besides that, song can be an interesting way to make the learners 
become excited to learn English especially in speaking. Song also have repetition which attached to the structure of song (Ningsih, 2019). Repetition itself means that a song is not only includes language patterns but also increase students' ability to pronounce, listen, feel the song, and provides a pleasant condition. Even though the learners listen to the song several times, they will not feel bored because it makes them happy and excited. Besides, Supiyati et al., (2020) found that the practice of speaking English through songs can support the learners to improve their pronunciation and it also can be useful for them to speak English well and correctly. Furthermore, the advantage of songs for students in honing their speaking skill will make them easy in interpreting and understanding the meaning and they can be more understood with the situation of the songs based on the lyrics or background of the singer.

As the explanation which stated above, the use of songs can be an innovative learning media to help the students in enhancing their speaking skill effectively. Regarding to the related previous study, it showed that the use of English songs was effective to increase students' speaking skill through utilize difference theme of song such as the alternative rock songs (Kirmantoro, 2014), acoustic English songs (Kamal et al., 2014) and determine students' perception to support their English through using songs (Ranggen, 2016).

Regarding with the previous research which inspected by Kamal et al., (2014), the researcher used pre-experimental research and the population is students of tenth grade of PPM Al-Istiqamah, Palu, Indonesia. The researchers gave pre-test first before treatment was applied for the learners to know the students' ability in speaking skill. The result of pre-test showed the mean score were 25.45 which indicate that speaking ability of students at tenth grade have low in speaking. Then, the researchers give a treatment for the learners after pretest through applying acoustic song. After that, students given post-test to measure the understanding of students after doing the treatment and the score increase become 45.75 . Therefore, it showed that the implementation of song as media to increase students' speaking ability was improved significantly.

In line with this study, Disney movies soundtrack chosen as the English songs media to measure that there is an improvement of students' speaking skill. The Disney movie itself has a special song that talks about the storyline of the film and there are many interesting meanings through the movies. The soundtrack songs were also very suitable to be heard by various age groups ranging from children to adults. As usual, Disney movies always formed as musical dramas so that the soundtrack of each film was widely known by people. 
In addition, there is another previous study which also used Disney song (Rohma, 2018), but it was only found the results of strategies in interpreting song lyrics based on translation studies. However, there is no the implementation of Disney song towards students' speaking skill. Therefore, this study chooses English song as the learning media to determine the effect of Disney movies soundtrack for the eleventh-grade students at Islamic boarding school in honing their speaking skill effectively.

\section{METHODOLOGY}

This study used quasi-experimental to determine the effect of Disney movies soundtrack in teaching speaking skill. Quasi-experimental is an experiment that the smallest experimental unit is given to the experimental group and control group is not chosen randomly (Hastjarjo, 2019). Moreover, quasi-experimental known as a research method which has the purpose to find the relationship of cause and effect without conducting randomization in collect the data (Sani, 2018). In quasi-experimental, there are two types of design such as time series design and non-equivalent control group design. The design which applied in this study is non-equivalent control group design because this type almost same with pretest-posttest control group design, but the experimental and control in this design were not chosen randomly. In this design, both results of control and experimental class are compared, and each group is selected and placed without randomization. Both of groups were given a pretest to determine the initial state and the difference between control and experimental class. Then, the results of pre-test can be said to be good if the pre-test scores of control and experimental group are not significantly different.

The population of this study was the eleventh-grade students an Islamic boarding school in Sidoarjo, East Java, Indonesia. The eleventh grade in this school consists of four classes which divided into two major such as XI-MIPA and XI-MIPS. Meanwhile, there are only two classes used in this study as the sample such as XI-MIPA 2 and XI-MIPS 2. Each class consists of 35 students and both class is taught by the same English teacher. As the sample in this study, XI-MIPA 2 chosen by the researcher as experimental group that was taught by implemented Disney movies soundtrack as treatment in the learning process. XIMIPS 2 chosen as the control group without applied the treatment and it was only taught using conventional learning.

In this study, data was collected by using pre-test and post-test. The test was used to measure that there is a good effect after applying the treatment through using Disney movies soundtrack towards students' speaking skill. Meanwhile, the pre-test and post-test difficulty 
levels are made equal. The test assessment in pre-test and post-test are same to ask the students sing the English song in front of the class one by one and they also should explain the moral value behind the song. Nevertheless, the post-test in control group, the learners just sing their favorite English song while in the post-test students should sing a song which became the soundtrack of Disney movies. Besides, the data in this study were analyzed by using independent sample t-test but the researcher must to test requirements analysis which includes normality test and homogeneity test. The purpose of normality test and homogeneity test before analyzing the results of independent sample t-test were to measure that the data were distributed normal and can be declared homogeneous.

Regarding with the procedures of experiments, there is a different treatment between control class and experimental class. In control class, the teacher only taught the material using conventional learning without implemented and practice speaking skill using Disney movies soundtrack (Figure 1). In contrast, there is the implementation of using Disney movies soundtrack as the treatment in experimental class (Figure 2). The treatment in this study was conducted in three hours of one-day treatment. In conducting the treatment in experimental class, the researcher takes place as temporary English teacher which gives the material of topic based on basic competence and the song chosen is a soundtrack song from Disney movies.

In this study, there are 4 soundtrack songs from Disney movies that used by the researcher in conducting the treatment, including 2 songs from Aladdin and 2 other songs from Frozen. The first song from Aladdin movie that applied in the treatment entitled $A$ Whole New World. This song has the meaning that happiness was not look at a person's social status, but it can also be felt even if only in a simple way. Then, another soundtrack song that has a deep meaning entitled Speechless. The meaning that can be drawn from this song was a woman must keep the spirit and must not give up in fighting injustice and this song also carries the message that women deserve to voice their opinions firmly.

Furthermore, there are 2 popular songs from the Frozen movie which applied in the treatment. The first song entitled Let it Go. The meaning of this song was also very inspiring especially for the teenagers. This song has the meaning that humans must be able to fight their fears and sorrows so that they can become strong and accept the shortcomings that exist in each of them. Then, the second soundtrack song from Frozen which applied in the treatment was entitled Do You Want to Build a Snowman. This song has a deep message from a little sister who really wants her sister's figure to be cheerful and attention back to her 
The Effect of Disney Movies Soundtrack to the Eleventh Grade Students' Speaking Skill at Islamic Boarding School

Alda Indah Permana, Fika Megawati

because after a long time her sister has never appeared in front of her. In addition, the lyrics of this song were also very listening so that it was very easy for the listeners to memorize and catching the meaning. Regarding with Disney soundtrack songs which applied in the treatment, all of the song has pop genre.

On the other hand, the material given for students is about meaning through music and this topic was chosen based on the basic competence through lesson plan. After the researcher explained the learning material, the learners should follow the instruction to find out the moral value of the song which presented in Power Point slide. The instruction contain about steps that must be known by students to figure out the meaning of song. Then, all of the students can discuss about the meaning of song in Disney movies which played by the researcher. After finished the discussion, the researcher asked students to prepare a song by soundtrack of Disney movies which they like the most. The researcher also asked the students to present their performance in singing a Disney song in front of the class one by one at the next meeting. Then, students should explain the moral value of the song clearly. The student's presentation will be the post-test of this research.

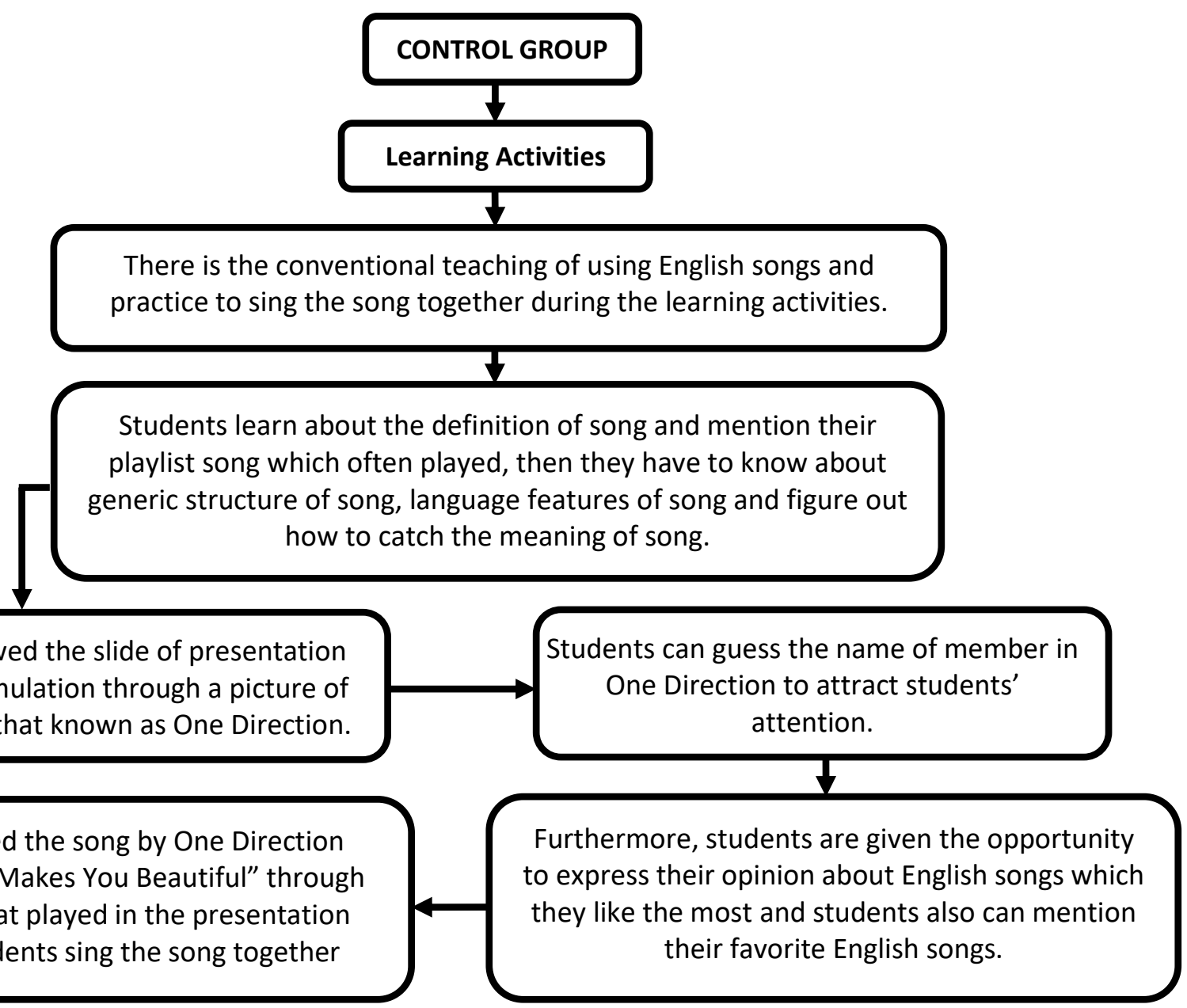

Figure 1. Teaching Process in the Control Group 


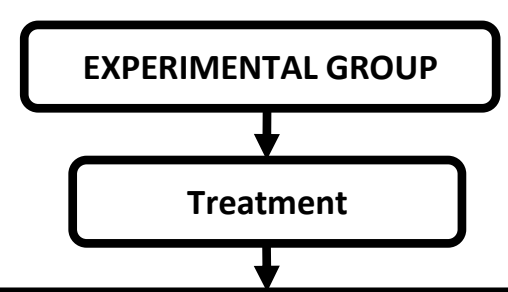

There is the implementation of using Disney songs and practice to sing the song together during the learning activities.

Students learn about the definition of song and mention their playlist song which often played, then they have to know about generic structure of song, language features of song and figure out how to catch the meaning of song.

Teacher showed the slide of presentation and gives stimulation through a picture of Disney movies and some actors who played in the movie.

Teacher played the soundtrack of Aladdin and Frozen movies through video that played in the presentation slide and students sing the song together
Students can guess the name of movies and the actors name to measure how interested students with Disney movies.

Figure 2. Teaching Process in the Experimental Group

\section{FINDINGS}

\subsection{The Score of Pre-test and Post-test}

The results score of pre-test and post-test in control group and experimental group showed in the table 1. Moreover, it showed that the score of pre-test and post-test in control class have an average value of 57.91 for the pre-test and 67.77 in the post-test. Meanwhile, the average score of pre-test in experimental group was 59.62 and 79.71 in the post-test. The gained score of pre-test and post-test in control group was 9.85 and 20.08 in the experimental group.

Table 1. The Score of Pre-test and Post-test in Control Group and Experimental Group

\begin{tabular}{lllc}
\hline Class & & Mean & Gained Score \\
\hline Control Group & Pre-test & 57.91 & 9.85 \\
& Post-test & 67.77 & \\
Experimental Group & Pre-test & 59.62 & 20.08 \\
& Post-test & 79.71 & \\
\hline
\end{tabular}


The Effect of Disney Movies Soundtrack to the Eleventh Grade Students' Speaking Skill at Islamic Boarding

According to the data in table 1 , it can be concluded that there is a difference results between control class and experimental class. The results showed that in the experimental group, the effect of the implementation treatment using Disney movies soundtrack useful for the learners in honing their speaking skill. In contrast, score in the control group also increased but not significantly. Meanwhile, there are four aspects of speaking which improve in this study such as fluency, body language, appearance and comprehension. In the control class which not given treatment using Disney soundtrack movies showed that almost the students' scores were not too much improvement while students' scores in the treatment class have significantly effect.

\subsection{Preliminary Data Analysis}

Before calculating the independent sample t-test, the researcher should conducted preliminary data analysis which consisted of normality test and homogeneity test. The purpose of the normality and homogeneity test is to see whether the data is distributed normal and also the data can be said homogeneous or not. The researcher used Microsoft Excel and manual calculation to determine the normality and homogeneity data.

\subsubsection{Normality Test and Homogeneity Test}

The normality test has a purpose to know whether the research data were normally distributed or not. In this study, the normality test was carried out in the pretest and post-test of both groups. Moreover, the researcher tested the normality data by using Chi Square formula.

Table 2. The Result of Normality Test

\begin{tabular}{llccc}
\hline Group & $\mathrm{N}$ & $\boldsymbol{x}_{\mathbf{h}^{2} \text { count }}$ & $\boldsymbol{x}_{\mathbf{h}^{2}}$ table & Conclusion \\
\hline $\begin{array}{l}\text { Experimental } \\
\text { (Pre-test) }\end{array}$ & 35 & -34.802 & 11.070 & Normal \\
$\begin{array}{l}\text { Control } \\
\text { (Pre-test) }\end{array}$ & 35 & -51.853 & 11.070 & Normal \\
$\begin{array}{l}\text { Experimental } \\
\text { (Post-test) }\end{array}$ & 35 & -30.887 & 11.070 & Normal \\
$\begin{array}{l}\text { Control } \\
\text { (Post-test) }\end{array}$ & 35 & -44.239 & 11.070 & Normal \\
\hline
\end{tabular}

Based on the summary of data above, it is found that from each data $x_{\mathrm{h}^{2} \text { count }}<x_{\mathrm{h}^{2}}$ table at a significance level of 5\%. The results indicate that all research variables of the data are normally distributed. 
Furthermore, homogeneity test is used to know whether the distribution of data homogeneous or not. Homogeneity test in this study was carried out in the pre-test and post-test both in the control and experimental class.

Table 3. The Score Result of Homogeneity Test

\begin{tabular}{|c|c|c|c|c|c|c|}
\hline Group & $\mathrm{N}$ & Average & Variants & $F_{\text {count }}$ & $F_{\text {table }}$ & Criteria \\
\hline $\begin{array}{l}\text { Experimental } \\
\text { (Pre-test) }\end{array}$ & 35 & 59.6 & 45.4 & 2.27 & 4.14 & Homogeneous \\
\hline $\begin{array}{l}\text { Control } \\
\text { (Pre-test) }\end{array}$ & 35 & 57.9 & 0.02 & 2.27 & 4.14 & Homogeneous \\
\hline $\begin{array}{l}\text { Experimental } \\
\text { (Post-test) }\end{array}$ & 35 & 79.7 & 40.9 & 1.10 & 4.14 & Homogeneous \\
\hline $\begin{array}{l}\text { Control } \\
\text { (Post-test) }\end{array}$ & 35 & 67.7 & 45.1 & 1.10 & 4.14 & Homogenous \\
\hline
\end{tabular}

In this study, the level significance used is $5 \%$ and it showed that $F_{\text {table }}$ is 4.14 while if the $F_{\text {count }}<F_{\text {table }}$ then $H_{0}$ is accepted or homogeneous. It can be conclude that in pre-test $2.27<4.14$ and in post-test found results $1.10<4.14$. Therefore, the pretest and post-test in this study has fulfilled the requirements of homogeneity and the hypothesis test can be continued.

\subsection{Hypothesis Test}

After the prerequisite test has been carried out, the next calculation is found the research hypothesis by conducting independent sample t-test. Moreover, the independent sample t-test is used to make a statement whether the research hypothesis is accepted or rejected.

Table 4. The Score Result of Independent Sample T-test

\begin{tabular}{lcccccc}
\hline & $\boldsymbol{X}_{\mathbf{1}}$ & $\boldsymbol{X}_{\mathbf{2}}$ & $\left(\boldsymbol{X}_{\mathbf{1}}-\boldsymbol{X}_{\mathbf{1}}\right)^{2}$ & $\left(\boldsymbol{X}_{\mathbf{2}}-\boldsymbol{X}_{\mathbf{2}}\right)^{2}$ & $\boldsymbol{T}_{\text {count }}$ & $\boldsymbol{T}_{\text {table }}$ \\
\hline Total & 79.7 & 67.7 & 1388.889 & 1536.35 & 7.692 & 1.995 \\
& & & & & \\
\hline
\end{tabular}

The results of t-test calculation with Hartley formula are seen from the significance level from $T_{\text {table }}$ with the provisions of degree of freedom $(\mathrm{df})=\mathrm{n}-2$ and obtained $T_{\text {table }}$ from $\mathrm{df}=$ 68 is 1.995 . Then, in the $T_{\text {test }}$ obtained $T_{\text {count }}>T_{\text {table }}(7.692>1.995)$, it means that $H_{0}$ is rejected. In addition, the conclusion of the result means that there are significant changes between student learning outcomes before and after using Disney movie soundtrack as the treatment.

\section{DISCUSSION}

The success of the learning process cannot be separated from the development of media which are oriented towards increasing the intensity of student involvement effectively. The importance of learning media that are used appropriately through the learning activities 
The Effect of Disney Movies Soundtrack to the Eleventh Grade Students' Speaking Skill at Islamic Boarding

will be more effective and efficient in supporting the media to help the students in achieving learning objectives (Puspitarini, 2019). It can be interpreted that the development of proper media aims to create learning conditions that allow the learners to learn actively and interactively so that learners can achieve optimal learning outcomes. Besides, the activities in this study were conducted through offline learning since the boarding school allowed the teacher and students have direct interaction in the classroom. Actually, the offline learning in one of high school can still be done as long as the health protocol is implemented in the learning process (Pratama \& Mulyati, 2020). Nevertheless, if the school regulations are tightened, teacher can do the learning activities through online learning as in Megawati et al (2021) study indicated that there is a planning for teacher if they want to have online class to applied Disney movie soundtrack for the students.

In this investigation, the researcher utilized the use of song as learning media to determine the effect on students' speaking skill. Siregar (2018) mentions that the use of song as a medium of learning can overcome students' difficulties in honing speaking and listening skills. Nevertheless, the researcher should consider the songs that will be chosen in carrying out learning process. Regarding the results of this study, Disney movie soundtrack was chosen as the learning media because there are many great moral values behind the song lyrics. As we know, the songs in Disney movies are famous for their meaningful lyrics and the meaning also not contain dirty words, unlike other western songs and the pop element in Disney songs very suitable for teenager (Mubarak et al., 2020). This is also in line with Akbary et al. (2018) who state that song lyrics have the potential to be an excellent source of information related to phrasal verb.

Further, the positive effect of the implementation Disney movies soundtrack on students' speaking ability enriched the study by Haghverdi (2015) who mention that the music and movie utilized in the study had a substantial impact on students' language success in hearing, reading, vocabulary, and grammar. In addition, Goering and Wei (2014) found that popular songs contribute to "communicative exchanges" in English classes.

\section{CONCLUSION}

The implementation of Disney movie soundtrack for eleventh grade students at Islamic boarding school indicate as good media which can be applied by teachers in the learning process, especially in improving students' speaking skill. In connection with findings in this study, this media could make the learners have interest in speaking, and they were able to be more active and confident to speak in English. In addition, Disney movie 
soundtrack also made the students feel not bored in learning English so that it could facilitate the students in honing their speaking skill better. Hence, it can be concluded that there was significant effect of the application Disney movies soundtrack towards students' speaking achievement. In addition, this study can be a reference for the other researchers to conduct the next similar research. Meanwhile, the next researchers should be able to be more creative in making something different in term of song selection, basic competence adjustment and different educational levels of students.

\section{REFERENCES}

Akbary, M., Shahriari, H., \& Hosseini Fatemi, A. (2018). The value of song lyrics for teaching and learning English phrasal verbs: a corpus investigation of four music genres. Innovation in language learning and teaching, 12(4), 344-356. https://doi.org/10.1080/17501229.2016.1216121

Al Hosni, S. (2014). Speaking difficulties encountered by young EFL learners. International Journal on Studies in English Language and Literature. 2(6): 22-30.

Al-Sobhi, B. M. S. and Preece, A. S. Teaching English speaking skills to the Arab students in the Saudi school in Kuala Lumpur: problems and solutions. International Journal of Education \& Literacy Studies. 6(1): 1-11. https://dx.doi.org/10.7575/aiac.ijels.v.6n.1p.1

Goering, C. Z., \& Wei, H. (2014). Playback and feedback: Revelations of an "encoding, decoding" analysis of popular songs used to teach English in China. The Clearing House: A Journal of Educational Strategies, Issues and Ideas, 87(6), 270-277. https://doi.org/10.1080/00098655.2014.956680

Haghverdi, H. R. (2015). The effect of song and movie on high school students language achievement in Dehdasht. Procedia-Social and Behavioral Sciences, 192, 313-320.

Hastjarjo, T. D. (2019). Rancangan eksperimen-quasi. Buletin Psikologi. 27(2): 187-203. doi: https://doi.org/10.22146/buletinpsikologi.38619

Kamal, F. B., Rita, F. and Wahyudin (2014). Developing speaking skill of the tenth grade students through acoustic song. English Language Teaching Society. 2(1): 1-11.

Kirmantoro, D. H. (2014). Improving students' speaking skill through the use of alternative rock songs of the XI grade at SMA Negeri 1 Pleret in the academic year of 2013/2014. Skripsi, Yogyakarta, Universitas Negeri Yogyakarta.

Megawati, F., Mukminatien, N., Permana, A. I., Dewi, L. A. and Fitriati, F. (2021). Emergency remote teaching and learning: technology-based instructional plan across grade levels. Teaching English with Technology. 21(2): 112-126. 
Mubarak, A. A., Darwis, N. and Suaib, R. W. (2020). Using Disney's theme song to improve the students' listening skill at eleventh grade of SMAN 13 Bone. International Journal of Research on English Teaching and Applied Linguistics. 1(2): 62-66. doi: http://dx.doi.org/10.30863/ijretal.v1i2.1229

Ningsih, N. (2019). The effect of song in teaching English. English Language Teaching for EFL Learners. 1(1): 1-12. https://doi.org/10.24252/elties.v1i1.7413

Parmawati, A. and Inayah, R. (2019). Improving students' speaking skill through English movie in scope of speaking for general communication. ELTIN Journal. 7(2): 43-53. https://doi.org/10.22460/eltin.v7i2.p43-53

Pratama, R. E. and Mulyati, S. (2020). Pembelajaran daring dan luring pada masa pandemi $\begin{array}{llll}\text { Covid-19.Gagasan } \quad \text { Pendidikan } & \text { Indonesia. }\end{array}$ http://dx.doi.org/10.30870/gpi.v1i2.9405

Puspitarini, Y. D. (2019). Using learning media to increase learning motivation in elementary school. Anatolian Journal of Education. 4(2): 53-60. doi: https://doi.org/10.29333/aje.2019.426a

Ranggen, B. R. (2016). Students' perception on the support of English songs to students' English developments. Skripsi, Yogyakarta, Universitas Sanata Dharma Yogyakarta.

Rohma, I. A. N. (2018). An analysis of strategies and quality of song lyric translation on Disney movies soundtracks. Skripsi, Malang, UniveristasMuhammadiyah Malang.

Sani, F. (2018). Metodologi penelitian farmasi komunitas dan eksperimental.Yogyakarta: Deepublish Publisher.

Siregar, S. D. (2018). Using song as media in teaching English. Jurnal Bahasa dan Sastra. 3(1): 1-7. http://dx.doi.org/10.31604/linguistik.v3i1.1-7

Supiyati, R., Ashari, A. and Ni'mah, D. (2020). A qualitative study on the use of song to teach speaking skill. Jurnal Penelitian, Pendidikan, dan Pembelajaran. 15(14): 1-12.

Tuan, N. H. and Mai, T. N. (2015). Factors affecting students' speaking performance at Le Thanh Hien High School. Asian Journal of Educational Research. 3(2): 8-23.

Wahidah, F. S. (2016). Students' speaking problems and factors causing it. Jurnal LOGIKA. 16(1): 1-11.

Wijaya, T. W. (2018). The effectiveness of songs for teaching speaking.Journal of Foreign Language Teaching \& Learning. 3(2): 74-85. https://doi.org/10.18196/ftl.3231

Wiraningsih, V., Manurung, K. and Budi. (2016). Developing speaking skill through STAD at grade XI students. English Language Teaching Society. 4(2): 1-10. 